Joanna Ziarkowska

\title{
Across the Atlantic and Beyond: Tracing Cosmopolitan Agendas in Leslie Marmon Silko's Gardens in the Dunes
}

In Leslie Marmon Silko's 1999 novel Gardens in the Dunes, young Indigo of the Sand Lizard tribe is separated from her family and taken in by a Euro-American couple, Hattie and Edward, who take her on a trip through Europe. Indigo visits foreign places, contemplates unfamiliar landscapes, collects seeds from unknown plants, and talks to people representing diverse cultures. Despite the sense of separation from home which accompanies her throughout her journey, the Indian girl manages to establish emotional and spiritual connections which facilitate communication in spite of cultural differences. The young girl does miss her home, but at the same time she manages to trace a connection with her Native home in the strangest parts of the world. One may ask: Can the easiness with which Indigo inhabits foreign spaces and her empathic approach to people and creatures that she encounters endow her transatlantic travel with a cosmopolitan character? Is Indigo an Indigenous cosmopolitan?

Indeed, as the editors and contributors in this volume have observed, cosmopolitanism has recently reemerged as a valuable critical discourse, suitable for responding to the fast-paced and rapidly changing realities of the modern world, with a special emphasis placed on issues related to identity, culture, and society in the context of increased transnational mobility, technological advancement, and globalization. As has been noted by numerous scholars, the body of work which engages cosmopolitanism is very broad in scope and interdisciplinary, thus making the task of defining the term extremely challenging, if not impossible. In the most common and colloquial understanding of the term, cosmopolitanism is seen as standing in opposition to nationalism and is characterized by a detachment from national and local bonds, replaced by an embracement of humanistic sensibilities and the rich diversity of human practices. In the words of Pheng Cheah, one of the most renowned scholars in the field, "Cosmopolitanism is about viewing oneself as part of a world, a circle of political belonging that transcends the limited ties of kinship and country to embrace the whole of deterritorialized humanity" (3). Such an understanding of the concept dates back to the philosophy of the Cynics of the fourth century BC and later the Greek Stoics, who believed that individuals may exist as citizens of the world, balancing new and old loyalties in the name of an abstract commitment to other people of the world. In Immanuel Kant's reworking of the concept, cosmopolitanism is combined with democratic forms of governance and is seen as a rational method of linking nations together to act against any violations of political rights (Fine ix). Post-millennial applications, or new cosmopolitanisms, revolve around the original meaning of the concept, as in Martha Naussbaum's work, and simultaneously address 
the realities of post-9/11, highly digitalized, increasingly mobile realities of the twentyfirst century. In its most recent use, cosmopolitanism concerns itself with non-elite citizens, thus becoming divorced from an assumption that mobility must be tied to economic privilege and that being cosmopolitan indirectly denotes Euro-American origins. At the same time, an increased emphasis on the forced mobility of displaced persons - brought about by either political, military, economic or ecological crisessituates cosmopolitanism vis-à-vis globalization and the harsh dictates of transnational capitalism. Thus, following Cheah's persuasive argument, "cosmopolitanism and human rights are the two primary ways of figuring the global as the human. Both phenomena are generally viewed as placing actual and normative limits on the efficacy of national culture and the sovereignty of the nation-state, which is seen as particularistic, oppressive, and even totalitarian” (3). Viewed in such a framework, that is in relation to critical theories centered on race and ethnicity, it will be shown that cosmopolitanism emerges as a form of consciousness, "that erodes national parochialism and facilitates the arduous process of establishing a platform for transnational political regulation" (Cheah 4).

Interestingly, literary theory has also turned its attention to cosmopolitanism, as a useful concept to expand and elaborate the fields of postcolonial studies, border studies, and, perhaps most provocatively, Native American and Indigenous Studies. Writers as diverse as James Joyce, Joseph Conrad, Virginia Woolf, Kazuo Ishiguro, Gertrude Stein, Jamaica Kincaid, J.M. Coetzee, Zadie Smith, and Teju Cole have been explored as pursuers of cosmopolitan themes and agendas in Jessica Berman's Modernist Fiction, Cosmopolitanism, and the Politics of Community (2001), Katherine Stanton's Cosmopolitan Fictions (2006), Rebecca Walkowitz's Cosmopolitan Style: Modernism Beyond the Nation (2006), Berthold Schoene's The Cosmopolitan Novel (2010), Robert Spencer's Cosmopolitan Criticism and Postcolonial Literature (2011), and most recently Kristian Shaw's Cosmopolitanism in Twenty-First Century Fiction (2017). While in some of the works analyzed in these publications the engagement of cosmopolitanism appears to be a logical and much needed approach (consider, for example, the inspiring discussions of transnational and cosmopolitan communities in Zadie Smith's NW and Teju Cole's Open Cities), the application of the concept in the field of Native American studies, whose preoccupation with the local and its histories is one of the most defining characteristics, brings about a number of striking conclusions.

The publication of N. Scott Momaday's (Kiowa) House Made of Dawn in 1968 and the subsequent Pulitzer Prize for its author spurred an unprecedented interest in and proliferation of Native American literature, a phenomenon termed by Kenneth Lincoln as a "Native American Renaissance" (8). Together with numerous publications by Native writers, attempts soon followed to theorize an emerging body of literary works, produced predominantly by scholars of Anglo-American origins. These first critiques of Indian literary works did not address the question of an exclusively Native methodology (or the lack thereof), the assumption being that the Western critical tradition offers ample ways of interpreting literary texts authored by indigenous writers, with 
Mikhail Bakhtin's theory of polyvocality being most widely applied to Native texts. Meanwhile, indigenous critics and writers began to voice their concerns about the troubling domination of Euro-American approaches in the study of Native American literatures and cultures, viewing many of the practices in the field as yet another form of colonialism. One of the first ground-breaking texts in the emerging Native American studies was Robert Warrior's (Osage) Tribal Secrets: Recovering American Indian Traditions (1995). In his insightful analysis of the works of Vine Deloria (Standing Rock Sioux), and John Josephs Mathews (Osage), Warrior postulates that the explosion of Native American writings after 1969 made it possible to create a critical methodology, an "intellectual sovereignty" in which both Native and non-Native critics engage with the more-than-two-century long tradition of Indian cultural productions. In other words, Warrior calls for interpretations of Native texts that proceed primarily from Native sources rather than Euro-American critical theory, thus drawing attention to the fact that, contrary to common beliefs, there exists an indigenous tradition from which provides theoretical tools to both critics and writers alike. Attempts to apply Warrior's ideas soon followed: Jace Weaver's (Cherokee) That the People Might Live: Native American Literatures and Native American Community (1997); Craig Womack's (Creek/Cherokee) Red on Red: Native American Literary Separatism (1999); Weaver, Womack, and Warrior's American Indian Literary Nationalism (2006); Lisa Brook's (Abenaki) The Common Pot: The Recovery of Native Space in the Northeast (2008); and an extremely influential collection of essays edited by Womack, Daniel Heath Justice (Cherokee), and Christopher B. Teuton (Cherokee), Reasoning Together: The Native Critics Collective (2008). What these publications have in common-indeed insist on-is a focus on the Native theory that emerges from the impressive body of Native writings and engages tribal communities at the cultural, historical, and political levels. The criticism born out of these considerations is never divorced from indigenous knowledge systems and cultural practices; it is committed to social realism, and thus may be seen as a form of activism.

Even a brief glance at the titles of these publications reveals a preoccupation with concepts such as nationalism and separatism, strongly insisting on Native sovereignty, self-governance, and the unique character of both the histories and the contemporary realities of respective tribes. In this context, one might ask whether there exists a critical space that invites cosmopolitan agendas into these strongly nationalist positions?

A direct response to such a question can be found in Arnold Krupat's Red Matters, which wholeheartedly embraces cosmopolitan theories in Native contexts. In fact, along with cosmopolitanism and indigenism, Krupat sees nationalism/separatism as one of the three dominant contemporary critical perspectives in Native American studies, which instead of contradicting one another, "are all overlapping and [are] interlinked so that each can only achieve its full coherence and effectiveness in 
relation to the others" (1). ${ }^{38}$ Nationalism and separatism in Krupat's framework are concepts which rest solely on Native sovereignty, as derived from the treaty-making practices of the United States government; and despite differences in cultural and historical contexts, are "also marked by post-World War II anticolonial nationalism" (4). In practice, Native American nationalist criticism attempts to "extend the political meanings of sovereignty to the realm of culture" (4) and to apply them in analyses of Native American literature. An indigenist perspective, on the other hand, shifts the emphasis from the political to the epistemological. "Indigenists," explains Krupat, "look to a particular relation to the earth as underlying a worldview that can be called traditional or tribal. It is this worldview that determines one's perspectives on literature as on all else, often regardless of national allegiances or statuses (e.g. whether one is or is not a 'citizen' of a particular Native nation or one of the people; whether one's community has greater or lesser amounts of sovereignty)” (10). The indigenist perspective, with its preoccupation with the earth and the ecological, offers a smooth transition to Native cosmopolitanism, which in Krupat's view reads Native literatures "in relation to other minority or subaltern literatures elsewhere in the late-colonial or postcolonial world" (19). Thus, in this approach Native cosmopolitanism "must always in some degree be comparative" (19) and inevitably finds affinities with postcolonial perspectives. ${ }^{39}$ While similarities in the agendas concerning Native American studies and postcolonial studies are strikingly visible, the automatic assumption of the compatibility of the two discourses remains problematic, a fact which Krupat seems to ignore. The three perspectives that he describes are seen as available paradigms to choose from when approaching Native American texts, often functioning in a relation of interdependence. "I need to repeat," writes Krupat, "that nationalist positions also need other positions, those of indigenists (as persons with different bodies of systematic knowledge) and cosmopolitans (as persons who can translate between different bodies of knowledge), for their anticolonial projects to succeed (for them not to replicate colonialism under another name or to become 'neurotic' entities)" (7). In this framework, cosmopolitanism in Native criticism is based on a natural reaction of affinity with other colonized and oppressed groups of the world.

Krupat's framing of Native American studies in the wider context of postcolonial studies is enthusiastically embraced by Elvira Pulitano in her widely debated and controversial Toward a Native American Critical Theory. However, instead of reconciling nationalist and postcolonial positions as Krupat does, Pulitano rejects point blank nationalist, separatist-or in Womack's terms-'tribally-centered discourses' as

38 In an essay published in 2013, "Nationalism, Transnationalism, Trans-Indigenism, Cosmopolitanism: Four Perspectives on Native American Literatures," Krupat revises his position and talks about four dominant perspectives: nationalism, transnationalism, trans-indigenism, and cosmopolitanism. 39 This kind of criticism is successfully practiced by Chadwick Allen. See Allen's Blood Narratives and Trans-Indigenous. 
insufficient to account for the level of hybridization that inevitably, after centuries of cross-cultural contact, characterizes Native literature. Consequently, in Pulitano's view, their approach becomes a yet another oppressive and one-dimensional framework, which privileges indigenous elements and silences and refuses to acknowledge the significance of non-Native influences. In a conclusion to her chapter on Warrior and Womack, Pulitano emphatically argues that: "Embracing literary separatism, and refusing to acknowledge their implications in the dominant discourse, Warrior and Womack end up ... perpetuating the discursive paradigms of Eurocentric thinking, thus further marginalizing Native American literature and theory, consigning it to the role of the Other of the Euroamerican consciousness" (100). Thus, in her evaluation of contemporary Native American writers Pulitano clearly favors and appreciates those who willingly and openly embrace the concept of hybridity and discourses of postcolonial studies, with Gerald Vizenor serving as a model of what Native American literature should become. ${ }^{40}$

Indeed, looking at Weaver's, Womack's, and Warrior's respective works and their shared response to Pulitano's book complicates the claim that Native American nationalism operates solely on a local level, hermetically sealed off from both mainstream US as well as global issues. The emphasis on tribal contexts and an insistence on their significance for Native literature are voiced forcefully and frequently, but it seems their function is, first of all, to defend against intellectual colonialism, practiced in the form of applying Western high theory to Native realities. While such a preoccupation with the indigenous issues may indeed downplay the usefulness of Western methodologies, it does not necessarily separate Native writing from the outside world and non-Native critics. As Weaver emphasizes in the first chapter of American Indian Literary Nationalism: "American Indian Literary Nationalism is separatist, but it is a pluralist separatism. We are splitting the earth, not dividing up the turf" (74). More importantly for any discussion of cosmopolitanism in indigenous contexts, Womack in his chapter convincingly refutes the vision of Native literature as separated from allusions to and influences of non-Native sources:

Just as tribes are related to the outside world of local municipalities, state governments, federal Indian law, and international relations (American Indian presence on U.N. task forces on indigenous peoples being a key example), literary nationalism can do local work with global implications, thus demonstrating a more profound cosmopolitanism than has been argued for to date, one with strong roots at its base. (168-169)

40 It is important to note, however, that Vizenor does not uncritically embrace postcolonial discourses and their implications for indigenous peoples in the United States. He consistently emphasizes the fact that in the case of indigenous populations, colonialism, be it cultural or economic, is not a matter of the past. Therefore, he proposes the term "paracolonial." See Vizenor, Manifest Manners. 
While for Pulitano this appears to be a paradoxical connection, the pairing of the local and the cosmopolitan is interestingly approached in Tol Foster's "Of One Blood: An Argument for Relations and Regionality in Native American Literary Studies,” published in Reasoning Together. Foster acknowledges Krupat's input into the debate, but his own contribution seems to offer a more complex and nuanced form of Native cosmopolitanism. While appreciating and supporting tribally specific approaches to literature, Foster advocates "relational regionalism" which focuses on how tribes, rather than functioning in isolation as separate cultural and geographical enclaves, in fact participate in a number of interactions with their close and further-away neighbors. What occurs during such cultural transactions is a redefinition of geographical space, from the unfamiliar to the familiar, and, more importantly, an interaction on an epistemological level which expands the boundaries of the "tribal archive" to neighboring cultures and beyond: "Thus, Native cosmopolitan ... is the practice of noticing and interacting with the multiple communities of any given place” (296). Will Rogers (Cherokee) serves as Foster's example of a Native cosmopolitan who manages to extend his special and cultural relations in any direction. Born into a wealthy family in 1879 in Indian Territory, Rogers left for South America, and later Africa, to regain the land holdings that his family had lost after 1906 with the dissolution of Indian Territory and the creation of Oklahoma in 1907. Unable to support himself, he entered show business as a traveling trick roper dubbed "The Cherokee Kid" and was soon engaged by Ziegfield's Follies in New York City, becoming a professionally and financially successful US actor. In his encounters with different cultures and traditions,

Rogers extended his notion of community outwards to the United States itself. Rogers engaged in a rhetoric, and I would argue a pedagogy, of relation by imagining himself in relation to his colonizers, and imagining a relation between his colonizers and the colonized of the world. He pursued his critique not through an argument of particularized experience (though that is where he learned it) but through the notion of a common relation. (288)

In other words, Foster draws attention to the power of Native literature to reach outside itself to other communities and cultures and establish powerful, long-lasting connections, which in turn influence all the participants of such interactions.

This turning away from a strict emphasis on nationalist issues in Native American studies, emphasizing instead the field's transnational and cosmopolitan dimension, has become more and more pronounced in Native American studies. In Mapping the Americas, Shari Huhndorf announces a shift away from nationalist orientations to transnational ones, whose presence she detects in early texts like Simon Ortiz's essay “Towards a Native American Nationalism,” which ironically Warrior, Weaver, and Womack identify as a foundation for Native American nationalism. "Transnationalism," writes Huhndorf, "refers to alliances among tribes and the social structures and practices that transcend their boundaries, as well as processes on a global scale such as colonialism and capitalism" (2). In examining the ways in which colonialism has reshaped Native cultures and posing questions about how indigeneity chal- 
lenges global capitalism, such a viewpoint directly addresses many issues present in cosmopolitan thinking. Huhndorf acknowledges that in the twenty-first century reality tribes cannot remain preoccupied solely with the local and are being drawn into global relationships, which in consequence lead to the creation of global identities. While Mapping the Americas does not openly identify with cosmopolitan thinking, the chapter devoted to an analysis of Leslie Marmon Silko's Almanac of the Dead (1990) is clearly influenced by such an approach.

Similarly, in recent publications Jace Weaver and Chris LaLonde approach cosmopolitanism as a paradigm whose application in Native American studies does not need justification and is simply taken for granted. LaLonde examines cosmopolitan positions vis-à-vis mixed blood identities, which are so abundant in Native American fiction. Examining the works of Gerald Vizenor, Louis Owens (Choctaw/Cherokee), and Linda Hogan (Chickasaw), LaLonde demonstrates how negotiating a mixed blood identity, or in Vizenor's language, "the state of being a 'crossblood,' " necessitates engagement with local tribal contexts as well as outside (including global) contexts. Furthermore Weaver, drawing inspiration from Paul Gilroy, in his impressive The Red Atlantic demonstrates how Native Americans, rather than being marginal figures, fully participated in the transfer and circulation of people, goods, ideas, and technologies: "Native resources, ideas, and peoples themselves traveled the Atlantic with regularity and became among the most basic defining components of Atlantic cultural exchange" (17). More importantly, Weaver discusses Native individuals crossing the Atlantic not solely as passive victims of colonialism and imperialism, but as agents of these numerous cultural and economic transactions, with obvious benefits for all the participants. Weaver observes:

The Atlantic formed a multilane, two-way bridge across which traveled ideas and things that changed both Europeans and American indigenes. Some scholars see in the cosmopolitanism and hybridity of Indians and their cultures a loss of indigenous authenticity, a diminution of Indianness. Such a position fails to account for the fact that Natives and their cultures had always been highly adaptive, appropriating and absorbing anything that seemed useful or powerful. (30; emphasis added)

In Weaver's and LaLonde's texts, Native cosmopolitanism is not a concept whose application needs validating and justifying, but should be simply taken for granted as a position that serves as a starting point for further considerations rather than an anomaly in critical tendencies.

The final example which works in tandem with Huhndorf's, LaLonde's, and Weaver's works is the 2010 collection Indigenous Cosmopolitanisms, edited by Maximilian Forte. In his Introduction to the volume, Forte, echoing Weaver's observations in The Red Atlantic, first of all dismisses a concept of indigeneity that is inextricably restrained to the local, rooted in one separate place and yet simultaneously suffering from the actions of the outside world and being seriously influenced by its political schemes. Instead, indigeneity in the twenty-first century is transnational, transcul- 
tural, and cosmopolitan, and this particular reincarnation of cosmopolitanism does not trace its origins in Greece, but in "the emergence of the Atlantic commercial circuit in the sixteenth century that linked the Spanish Crown with the capitalist entrepreneurs from Genoa, with Christian missionaries, with Amerindian elites, and with African slaves" (qtd. in Forte 4). "Indigenous cosmopolitanisms" are understood as "vernacular cosmopolitanisms" that "can be rooted and routed, nonelite yet nonparochial, provincial without being isolated, internationalized without being de-localized” (6). In other words, 'Indigenous cosmopolitanism' is, in its different manifestations, a rational and strategic reaction to the spread of neoliberal capitalism and its consequences, a reaction that sees the necessity of creating transnational and transcultural alliances without forsaking one's sense of place and identity. What Forte's paradigm and the Native American cosmopolitan orientation have in common can be well illustrated by Kwame Anthony Appiah's widely debated concept of a "cosmopolitan patriot." In a 1997 essay, Appiah writes: "the cosmopolitan patriot can entertain the possibility of a world in which everyone is a rooted cosmopolitan, attached to a home of one's own, with its own cultural particularities, but taking pleasure from the presence of other, different places that are home to other, different people" (qtd. in Forte 8).

As LaLonde has observed, cosmopolitan orientations in Native American literature manifest themselves in a number of themes and approaches to Indianness and its engagement with the surrounding US and global contexts. There are writers, such as Vizenor, Owens, and Hogan, whose oeuvres are not readily identified as part of cosmopolitanism, and yet their thematic choices and discursive strategies easily lend themselves to such a reading. Similarly, Silko's Gardens in the Dunes, while critically analyzed in numerous publications (Barilla; Fitz; Gercken; Tillett), has not been interpreted as a novel with a cosmopolitan agenda. What follows is an attempt to read Gardens as a text which skillfully combines Native, tribal, and local issues with more diversified contexts of the modern world, thus supporting, albeit indirectly, the cosmopolitan leanings of Native texts. Moreover, since the novel is set in the nineteenth century, it demonstrates a wider spectrum of Native American cosmopolitanism, going beyond the customary allusions to post-millennial political and transcultural contexts.

Gardens in the Dunes returns to themes that Silko has explored in her previous novels: indigenous opposition to cultural and geographical colonization, different scenarios of revolutionary acts against Western power, and the transitional character of Native cultures, which constitutes their most distinctive and powerful feature. As Terre Ryan observes, it is, however, above all "a subtly crafted history of nineteenthcentury European and North American imperialism" as "it encompasses the conquest of the Americas, botanical piracy, genocide, forced Christianization, and acts of violence against women, indigenous peoples, and the earth" (115). As stated at the beginning, the novel revolves around and is often focalized through the figure of Indigo, of the Sand Lizard People, a fictional tribe inspired by many Colorado River tribes, 
and one which has been destroyed at the time of the events in the story (Arnold 172). Indigo is separated from her mother and older Sister Salt and placed in the Sherman Institute in Riverside, California, from which she escapes and is taken in by Edward and Hattie Palmer. The transatlantic and transcultural narrative develops because Edward is a scientist and hobbyist botanist who attempts to make a profit on botanical commerce. It is Edward's and Indigo's distinct methods of interaction with the diverse cultures that they encounter during their travels that enriches the novel with a cosmopolitan angle.

However, if Edward Palmer is chosen as a character to introduce the cosmopolitan perspective, it quickly becomes clear that such a reading leads to a dead end. At first sight, with his extensive knowledge of the world and its flora, and frequent travels and contacts with foreign cultures, Edward does appear to be a "citizen of the world," comfortable at home and elsewhere. He easily impresses Hattie with his relaxed attitude to the experience of international travel, casting himself as a traveler curious about and at ease with new experiences: "He traveled a great deal to the most distant and fascinating destinations, and he had a wonderful gift for recounting his adventures, in which he portrayed himself humorously, as the innocent tourist hell-bent on disaster" (79). But in fact he is neither innocent nor cosmopolitan in his encounters with the foreign lands and cultures; rather, as will be shown, he epitomizes an exploitative form of transnational travel.

As Silko unfolds the story of Edward's expeditions, it becomes clear that his interest in plants is purely commercial. Samples of Brassavola nodosa, a small orchid with a gardenia-like smell, were the first cuttings he obtained with the intention of reselling at a profit. Despite his knowledge of the flower's sacred status for the local cultures, Edward's approach is purely commercial: “They'd be just the orchid to win over the public. Sun priests of the Maya reputedly held the orchid sacred because it invariably bloomed on the autumnal equinox. Flowers of the gods! He could imagine the ads in magazines now" (371). Sadly, the sacredness of the plant is important to Edward only in the context of boosting prospective sales to orchid collectors. Since he shows no respect for indigenous cultures and religions, the sacred status of the flower remains irrelevant to his schemes. This same logic is repeated during his Pará River expedition. As a business partner of Lowe \& Company, he meticulously searches the jungle for the rarest species of wild orchids in an attempt to improve his financial situation, undisturbed by the violent history of imperialism and slavery in which the beautiful flowers are implicated: "Now, the Indians knew the value of wild orchids, but frequently white brokers came upriver and demanded their entire stock of a species to corner a market. Indians who did not cooperate were flogged or tortured, much as they were at the Brazilian and Colombian rubber stations” (133). As Ryan observes, "The jungle scenes portray acts of gross violence in which the indigenous peoples and the land are murderously exploited in the name of commercial imperialism. The pilfered cuttings, we know, will be propagated and planted by the subjugated peoples of Britain’s Far Eastern colonies” (128). By emphasizing his role 
as a hobbyist, seemingly uninvolved in the colonialist enterprise, Edward attempts to escape responsibility for the exploitation of the land and of the indigenous people. But the very fact of his participation in stealing and transplanting indigenous plants for profit, a morally dubious project, renders him an agent of commercial imperialism rather than an innocent observer.

The instrumentality with which Edward approaches local plants is extended to the way he treats indigenous people. His contacts with the locals repeat the imperialist logic of the superiority of the white race: the Indians of the Para River are only useful for carrying heavy luggage and bulky camera equipment and when they help locate rare species of flowers; the mestizo brothers acquire human characteristics only when they save Edward's life by attending to his broken leg and transporting him safely to the boat. Similarly, Indigo is never a lost child in need of help, but is either useful as Hattie's maid or, in a different scenario, the last living representative of some Indian tribe whom he could photograph and study, which in turn would possibly make him famous in the academic world. Edward's interactions with nonwhite people are guided by disrespect for and fear of the physical and cultural other. When Edward visits a public market in Tampico, he spots meteorite stones on one of the stalls. Excited by his discovery, he pursues an old black woman who appears to be the owner of the stones. Surprisingly, the woman refuses to sell the stones and instead threatens Edward about the price he will pay in the future. Paralyzed with fear, Edward's perception concentrates on the woman's features as distinctly different from his own-all he sees is her dark complexion and "the woman's Maya features: sharp high cheekbones and an aquiline nose" (87). He cannot understand the source of contempt in her voice and her apparent lack of respect leaves him terrified: "She leaned her blue face and breasts closer, he felt the heat of her breath and instantly a terrible dread swept over him as if he was in imminent danger" (88). What these encounters succinctly demonstrate is that mentally Edward does not move beyond the imperialist and colonialist projects of the Western world which he represents, and therefore he utterly fails to epitomize the cosmopolitan spirit.

If, as Forte forcefully emphasizes, Indigenous cosmopolitans explore new routes in the world while simultaneously remaining loyal to their locales, then Indigo is a truly cosmopolitan traveler par excellence. The importance of the local, indigenous place and the epistemological systems tied to it is announced in the very title of the novel and is immediately emphasized in the opening pages. The first paragraph describes Indigo and Sister Salt dancing naked in the rain in the gardens in the dunes:

The rain smelled heavenly. All over the sand dunes, Datura blossoms round and white as moons breathed their fragrance of magic. Indigo came up from the pit house into the heat; the ground under her bare feet was still warm, but the rain in the breeze felt so cool-so cool-and refreshing on her face. ... She titled back her head and opened her mouth wide the way Sister Salt did. The rain she swallowed tasted like the wind. She ran, leaped in the air, and rolled on the warm sand over and over, it was so wonderful. She took handfuls of sand and poured them over her legs and over her stomach and shoulders-the raindrops were cold now and the warmth of the sand 
felt delicious. Over and over down-down-down-down effortlessly, the ease of the motion and the sensation of the warm sand and the cool rain were intoxicating. (13)

This lengthy passage succinctly demonstrates how Indigo is inextricably connected with her indigenous environment, or as Becca Gercken observes: “[W]ith the opening paragraph, Silko establishes that Indigo is not just on the land, she is of the land, as is her sister who enjoys the rain with her" (180). It is important to note here that Edward lacks this kind of connection with his locality. When Hattie arrives in her new home, the first thing she notices is an abandoned garden, weeded and uncared for (75).

Living in the gardens in the dunes entails following the harsh rules of the desert climate and mastering the art of living off of and in tandem with the land. It is Grandma Fleet, the girls' grandmother, who teaches them the rules for living in harmony with the environment, cherishing every plant and seed as a gift that needs to be returned:

\begin{abstract}
Sand Lizard warned her children to share: Don’t be greedy. The first ripe fruit of each harvest belongs to the spirits of our ancestors, who come to us as rain; the second ripe fruit should go to the birds and wild animals, in gratitude for their restraint in sparing the seeds and sprouts earlier in the season. Give the third ripe fruit to the bees, ants, mantises, and others who cared for the plants. A few choice pumpkins, squash, and bean plants were simply left on the sand beneath the mother plants to shrivel dry and return to the earth. ... Old Sand Lizard insisted her gardens be reseeded in that way because human beings are undependable. (15)
\end{abstract}

The gardens are thus an example of subsistence agriculture, which relies on plants indigenous to the area and successfully reuses all the resources. Gardens in the dunes, as farmed by Grandma Fleet and later Sister Salt and Indigo, are powerfully contrasted with the Euro-American gardens planted by the white characters. The most striking and grotesque example is Susan Palmer's Long Island garden in which all indigenous plants have been violently removed and instead trees and bushes from England have been replanted to create an association with the European elite and high culture. ${ }^{41}$ This juxtaposition serves to illustrate the very different approach to horticultural practices and the use of the land itself. From an indigenous perspective, the land is fundamental for the sustenance and survival of Indian tribes, literally as well as culturally.

While the Sand Lizard people emphasize their connection with the land, their interest in the outside world and respect for mobility are features that frame their uniqueness. Living in the gardens often entails a shortage of food, but Grandma Fleet would never agree to abandon her home and be hoarded into a reservation:

Reservation Indians sat in one place and did not move; they ate white food-white bread and white sugar and white lard.... Reservation Indians had no mesquite flower for the winter because they could not leave the reservation to gather mesquite beans in August. ... Poor people! If they

41 For an interesting discussion of gardens and horticulture in Gardens in the Dunes, see Tillett. 
couldn't travel around, here and there, they wouldn't be able to find enough to eat; if people stayed in one place too long, they soon ate up everything. (17)

Mobility and movement are thus not only features of resistance to the policies of cultural annihilation applied by the United States government towards Native Americans, but more importantly preconditions of sustenance and survival. Similarly, this openness to movement and encounters with the cultural other is expressed in the tribe's attitude to mixed blood children. Silko emphasizes this importance of mixing (of seeds as well as races) in the subplot concerning Sister Salt, who gives birth to a baby boy fathered by Big Candy, an African American: "Sand Lizard mothers gave birth to Sand Lizard babies no matter which man they lay with. ... The old-time Sand Lizard people believed sex with strangers was advantageous because it created a happy atmosphere to benefit commerce and exchange with strangers" $(202,218)$. Later in the novel, Sister Salt establishes a woman-centered community with her son, and the Chemahuevi twins, also displaced characters in the novel, are her closest friends. It is therefore equally the importance of the locality as well as flexibility (geographical as well as cultural), so often underlined in cosmopolitan theories, that are the founding stones of the Sand Lizard people's system of knowledge.

During her transatlantic and transnational adventures, Indigo cherishes the philosophies of her tribe, incorporated into Grandma Fleet's teachings, and at the same time remains perceptive about and receptive toward the new geographical and cultural environment around her. In stark contrast to Edward, Indigo approaches both the human and non-human creatures she encounters on her way with interest and empathy. Linneaus, a monkey brought from one of the expeditions (103-104), and the green parrot kept by Susan for decorative purposes (187) are set free from their cages and become the child's companions. Indigo also establishes a meaningful relationship with an Indian woman from the Oyster Bay area, who takes care of her for a brief time (169). Aunt Bronwyn, despite committing the sin of lumping all Indian people together, engages Indigo in an exploration of her ancient gardens and illuminates the similarities between Sand Lizard and ancient European mythologies (239, 244). These interactions are always marked by a process of mediation between what Indigo sees and her knowledge about the Sand Lizard culture, which can be applied in any circumstances. As Gercken points out, Indigo "does more than inhabit the space [which she visits], she indigenizes it" (181). Thus, the girl achieves the condition of being "at home" (with both people and places) despite a geographical separation from the gardens in the dunes.

Like Edward, following Grandma Fleet's lessons Indigo collects the seeds of the plants that she encounters. However, her actions are motivated by different aims than those of the botanist: "Grandma Fleet always advised the girls to collect as many new seeds as they could carry home. The more strange and unknown the plant, the more interested Grandma Fleet was; she loved to collect and trade seeds. Others did not grow a plant unless it was food or medicine, but Sand Lizards planted seeds to see what would come" (83-84; emphasis added). The movement of people and goods 
(seeds) improves the subsistence farming and promotes intercultural connections, instead of conceptualizing plants and seeds solely as goods in a commercial context, as was the case with Edward. According to James Barilla, since Edward "attempts to claim the original material, to name a new species after himself instead of acknowledging the plant's origins elsewhere and respecting its biological sovereignty, his collecting becomes piracy, the theft of natural and cultural capital, and the transfer of indigenous knowledge and material into a monetary system of exchange at unfair rates" (168).

As Indigo travels the world, she manages to draw parallels between the situation of her tribe and those of other peoples facing a similar predicament of land theft, economic exploitation, and cultural annihilation. When she returns home with Linnaeus, the green parrot, and a huge collection of seeds, she reconnects with her sister and they return to the area of the Sand Lizard people's gardens:

\footnotetext{
When the girls first returned to the old gardens the winter before, Grandma Fleet's dugout house was in good condition but terrible things had been done at the spring. ... Strangers had come to the old gardens; at the spring, and for no reason they slaughtered the big old rattlesnake who lived there; they chopped down the small apricot trees above Grandma Fleet's grave. ... Today Indigo and Linnaeus ran ahead of the others with the parrot flying ahead of her. At the top of the sandy slope she stopped and knelt in the sand by the stumps of the apricot trees, and growing out of the base of one stump were green leafy shoots. Who knew such a thing was possible last winter when they cried their eyes sore over the trees? (476)
}

The sprouts that appear in this unexpected place are from the "foreign," hybrid gladiolas whose seeds Indigo brought from her transatlantic travel with Hattie and Edward. Surprisingly, not only do the flowers grow in the dry terrain but also prove to be a valuable source of food. What seems to be significant in this last passage is not so much the miracle of the blooming hybridized flowers in the desert, but Indigo's simultaneous participation in the rebirth of the Sand Lizard garden and the formation of transcultural alliances, without forsaking her commitment to her land. Indigo's engagement with Indians from the Oyster Bay, locals in Corsica, Hattie's upper-class family, brilliantly illustrates Foster's idea of the "relational regionalism," of tribal people reaching out to other communities, as well as Weaver's cultural circulations on the Red Atlantic. What began for Indigo as a transatlantic voyage is transformed into a genuinely cosmopolitan experience.

In June 2017, during the 38th American Indian Workshop organized at King's Collage, London, LeAnne Howe (Choctaw) delivered a presentation that included an insightful comment on the discussion of Native American cosmopolitanism. In 1847, an unusual cooperation took place: despite living in poverty themselves, the Choctaw people collected $\$ 170$ (about $\$ 4,400$ today) to send food to Ireland when they heard about the famine in Europe. At that time, the Choctaws were suffering from the consequences of their forced removal from their Native lands, and yet "inspired by their tradition of giving 'without seeking things in return' ” (Smith), they demonstrated 
an immense sense of generosity, or perhaps a cosmopolitan orientation towards other non-elite and oppressed people of the world. The contacts then established continue today.

\section{Works Cited}

Allen, Chadwick. Blood Narratives: Indigenous Identity in American Indian and Maori Literary and Activist Texts. Duke UP, 2002.

---. Trans-Indigenous: Methodologies for Global Native Literary Studies. U of Minnesota P, 2012. Appiah, Kwame Anthony. "Cosmopolitan Patriots." Critical Inquiry, vol. 23, no. 3, 1997, pp. 617-639. Arnold, Ellen. "Listening to the Spirits: An Interview with Leslie Marmon Silko." Conversations with Leslie Marmon Silko, edited by Ellen Arnold, UP of Mississippi, 2000, pp. 162-196.

Barilla, James. "Biological Invasion Discourse and Leslie Marmon Silko's Gardens in the Dunes." Reading Leslie Marmon Silko: Critical Perspectives through Gardens in the Dunes, edited by Laura Coltelli, Pisa UP, 2007, pp. 165-176.

Cheah, Pheng. Inhuman Conditions: On Cosmopolitanism and Human Rights. Harvard UP, 2006.

--.. What Is a World?: On Postcolonial Literature as World Literature. Duke UP, 2016.

Fine, Robert. Cosmopolitanism. Routledge, 2007.

Fitz, Brewster E. Silko: Writing Storyteller and Medicine Woman. U of Oklahoma P, 2003.

Forte, Maximilian, editor. Indigenous Cosmopolitanisms: Transnational and Transcultural Indigeneity in the Twenty-First Century. Peter Lang, 2010.

Foster, Tol. "Of One Blood: An Argument for Relations and Regionality in Native American Literary Studies." Reasoning Together: The Native Critics Collective, edited by Craig Womack et al., $\mathrm{U}$ of Oklahoma P, 2008, pp. 265-302.

Gercken, Becca. "World of Water, World of Sand: Teaching Silko's Gardens in the Dunes and Sullivan's Star Waka." Leslie Marmon Silko: Ceremony, Almanac of the Dead, Gardens in the Dunes, edited by David L. Moore, Bloomsbury, 2016, pp. 177-190.

Huhndorf, Shari M. Mapping the Americas: the Transnational Politics of Contemporary Native Culture. Cornell UP, 2009.

Krupat, Arnold. "Nationalism, Transnationalism, Trans-Indigenism, Cosmopolitanism: Four Perspectives on Native American Literatures." Journal of Ethnic American Literature, no. 3, Jan. 2013, pp. 5-63.

---. Red Matters: Native American Studies. U of Pennsylvania P, 2002.

LaLonde, Chris. "Clear-Cut: The Importance of Mixedblood Identities and the Promise of Native American Cosmopolitanism to Native American Literatures." The Routledge Companion to Native American Literature, edited by Deborah L. Madsen, Routledge, 2016, pp. 92-104.

Lincoln, Kenneth. Native American Renaissance. U of California P, 1983.

Mignolo, Walter. "The Many Faces of Cosmo-Polis: Border Thinking and Critical Cosmopolitanism." Public Culture, vol. 12, no. 3, 2000, pp. 721-748.

Ortiz, Simon. "Towards a National Indian Literature: Cultural Authenticity in Nationalism." MELUS, vol. 8, no. 2, 1981, pp. 7-12.

Pulitano, Elvira. Toward a Native American Critical Theory. U of Nebraska P, 2003.

Ryan, Terre. "The Nineteenth-Century Garden Imperialism, Subsistence, and Subversion in Leslie Marmon Silko's Gardens in the Dunes." SAIL, vol. 19, no. 3, 2007, pp. 115-132.

Silko, Leslie Marmon. Gardens in the Dunes. Simon \& Schuster, 1999. 
Smith, Chris. "Remembering the Choctaw Nation's Gift to Ireland." English and Comparative Literature, www.gold.ac.uk/news/padraig-kirwan-choctaw/. Accessed 10 Dec. 2017.

Tillett, Rebecca. “'Sand Lizard Warned Her Children to Share': Philosophies of Gardening and Exchange in Silko's Gardens in the Dunes." Leslie Marmon Silko: Ceremony, Almanac of the Dead, Gardens in the Dunes, edited by David L. Moore, Bloomsbury, 2016, pp. 219-239.

Vizenor, Gerald. Manifest Manners: Narratives on Postindian Survivance. U of Nebraska P, 1994.

Warrior, Robert. Tribal Secrets: Recovering American Indian Intellectual Tradition. U of Minnesota P, 1994.

Weaver, Jace. The Red Atlantic: American Indigenes and the Making of the Modern World, 1000-1927. U of North Carolina P, 2014.

Weaver, Jace, et al. American Indian Literary Nationalism. U of New Mexico P, 2006. 